\title{
Utopianism in the Age of Capitalocene
}

\author{
Keijo Lakkala
}

Department of Social Sciences and Philosophy, University of Jyväskylä, Finland keijo.s.lakkala@student.jyu.fi

\begin{abstract}
This article explores the social and political imagination of 'the Anthropocene' and the utopian counter-images that can be derived from it. From the utopian studies perspective, I argue that the Anthropocene cannot provide sufficient societal alternatives for the current ecological predicament. This is due to the fact that the concept of Anthropocene relies too heavily on the image of abstract humanity to be able to offer real societal alternatives. It cannot name the social system we live in and, therefore, it cannot fundamentally challenge existing social arrangements. Based on utopian social theory, I conceptualize utopia as a counter-image of the present motivated by a desire for better being. The contents and the politically transformative potentials of utopian counter-images depend on the conceptualization of the present itself. I contrast the utopian potentials of 'the Anthropocene' with that of 'the Capitalocene' which is more apt in outlining the social conditions of the present. Thus, the Capitalocene as a concept opens up more radical possibilities for imagining societal alternatives by conceptualizing the present socially.
\end{abstract}

Keywords: utopianism, utopian studies, Anthropocene, Capitalocene, political imagination

\section{Introduction}

"In reality and for the practical materialist, i.e. the communist, it is a question of revolutionising the existing world, of practically attacking and changing existing things. When occasionally we find such views with Feuerbach, they are never more than isolated surmises and have much too little influence on his general outlook to be considered here as anything else than embryos capable of development. Feuerbach's conception of the sensuous world is confined on the one hand to mere contemplation of it, and on the other to mere feeling; he says 'Man' instead of 'real historical man.' 'Man' is really 'the German."' Karl Marx \& Friedrich Engels (1976: 39)

"Man is the last evil spirit or spook, the most deceptive or most intimate, the craftiest liar with honest mien, the father of lies." Max Stirner (1995: 165) 
This article explores some of the consequences that the concept of the Anthropocene might have on the social, political and, most of all, utopian imagination. Here, I am not referring to the geological or the natural scientific concept of the Anthropocene but to the social scientific and the political version of the Anthropocene that has pervaded popular discourse. I argue that the abstract 'concept of Man' or abstract humanity present in this discourse hinders our capability to imagine social alternatives. If the present epoch is conceptualized abstractly as "the epoch of Man" (the epoch of abstract Man, the epoch of Man in general), what kind of alternatives can we derive from this image of the present? I approach the topic from the fields of utopian studies and "utopian social theory" which studies among other things how utopias are used to explain social transformation (Sargent 2010: 7).

The argument of this article is based on the conceptual distinctions I have made in my forthcoming dissertation where I argue that there are roughly two ways to interpret the concept of utopia: absolutist and relationalist. The absolutist interpretation of utopia is a very particular one and hardly exhaustive. It approaches utopias as static models, the implementation of which can only take place in the manner of imposing a blueprint upon society. On this basis, it is easy to interpret utopias as signifying an imposition of totalitarianism, as opposed to liberty. Absolutist interpretations of utopias can take a variety of forms. Some absolutist aspects of utopias emphasized by different authors are moral monism, holistic methodology, and utopias as closed systems (Berlin 1997; Popper 1957; Popper 1963; Talmon 1952).

The absolutist position can be contrasted with the relationalist interpretation. Relationalism sees utopias as first and foremost criticisms and counter-images of the present. Relationalism is about offering alternatives and not about the perfect state of a social being. It is possible to think of utopia as an epistemological rather than ontological category. Utopian texts and conceptions can be understood as heuristic tools for social imagination rather than blueprints for an ideal society. The interest here is in the critical function of utopias and in the role of utopias in criticizing and relativizing the present by showing a radical alternative to it.

It should be noted here that I do not use the concepts of "absolutist" and "relationalist" as categories of utopias. I use them as interpretative frameworks through which different aspects of utopias become visible. Absolutist interpretation sees utopias as inherently rigid, static, and authoritarian. Relationalist interpretation on the other hand interprets utopias as open, historically sensitive, and dynamic. Both concepts express different ways of relating to the concept of utopia and the phenomenon of utopianism in general.

The distinction made here between absolutism and relationalism is intended as a statement in the discussions surrounding the relationship of utopias with totalitarianism. The historical experience of both fascism and Stalinism challenged utopian thought in the $20^{\text {th }}$ century and forced theoreticians of utopia to distinguish the desired forms of utopianism from the forms of utopia that were associated with totalitarianism. This created a need to make distinctions and oppositions between closed totalitarian form of utopianism and more open forms of utopia. For example, Erin McKenna (2001: 3) has written about the 
difference between "the end-state model of utopia" and "the process model of utopia", Russell Jacoby (2005: xiv) about the difference of "the blueprint tradition of utopianism" and "the iconoclastic tradition of utopianism" and David Harvey (2000: 169-189) about the difference between the "utopia of spatial form" and "utopia of social process".

In this article, I define utopia in a relationalist manner as a critical counter-image of the present motivated by a desire for a better being. This definition combines two formulations of the concept of utopia. On the one hand, this definition builds on the view that utopia should be seen as a radical alternative to the present and not as a perfect blueprint. As utopian scholar Gregory Claeys (2017: 44) has written: "Utopia is not synonymous with perfectionism, but represents a guided improvement of human behavior. Perfectionism is a religious category. Utopia is not." Utopia offers an image of an alternative social world that both mirrors the problems faced in the present and aims to overcome these problems. On the other hand, this definition of utopia sees the "desire for better being" as an important motivator for any counter-image. It names the orientation towards a radically different and significantly better world we can find from any counter-image of a utopian kind. This notion of the "desire for better being" is drawn from the work of utopian scholar Ruth Levitas (2010) who has defined utopia in general from the perspective of this desire.

From the definition offered above, utopia is an image of a radically different and significantly better alternative world. This image of an alternative, however, is dependent on the image of the present we draw through the analysis of our current historical situation. The notion of the Anthropocene offers one possible way to draw an image of the present. However, the counter-images derived from the Anthropocene usually revolve around an abstract notion of humanity and not around the social system we are living in. It cannot offer concrete social alternatives. In contrast, I examine the alternative notion of the Capitalocene which names the system we are currently living under, giving us the possibility to imagine alternative social systems through utopian counter-images. The Capitalocene outlines more specifically the social arrangements of the present (the class organization of the economy and the ecologically destructive capacities of capitalism) and provides more effective radical counter-image to this present. Here, I will rely mainly on the work of Jason W. Moore in formulating my positions on the concept of the Capitalocene.

The structure of this article is the following. In the second part of this article, I specify my position within utopian social theory and develop further the distinction between absolutist and relationalist interpretations of the concept of utopia. I will also offer my definition of utopia as a counter-image and elaborate on the different aspects of utopias as counter-images. After this, I will apply these conceptual distinctions to the discussions surrounding the concepts of the Anthropocene and the Capitalocene. In this section, I will distinguish two interpretations of the notion of Anthropocene: the "Good" and the "Bad" Anthropocene. The attribute 'Good' refers to a "utopian" understanding of Anthropocene where humanity is seen as Promethean force creating a utopia through the transformation of the Earth itself. The attribute 'Bad' on the other hand refers here to a more dystopian 
interpretation of the concept of Anthropocene. In the Bad Anthropocene, humanity is seen as a force that is destroying the Earth and the life on it irreversibly. Thus, I interpret the notion of the Anthropocene as a concept that can be coded in both utopian and dystopian ways. For better or for worse, the notion of Anthropocene offers a starting point for developing utopian counter-images and these counter-images can be either utopian or dystopian.

\section{On absolutist \& relationalist interpretations of utopia: utopia as counter-image of the present}

It is a very common criticism of utopian thought that utopia expresses a desire for impossible perfection and that this strive for perfection will inevitably cause violence and repression in the empirical world. This kind of criticism has been presented for example by Ralf Dahrendorf (1958: 116):

"Utopias are perfect - be it perfectly agreeable or perfectly disagreeable - and consequently there is nothing to quarrel about. Strikes and revolutions are as conspicuously absent from utopian societies as are parliaments in which organized groups advance their conflicting claims for power."

Utopias are seen as indicating perfect harmony. For example for Isaiah Berlin (1997b: 191), utopia is an aspiration to form a society based on metaethical monism and as a dream of "perfect social harmony" it is dogmatic, authoritarian and possibly fatal.

The possibility of a final solution - even if we forget the terrible sense that these words acquired in Hitler's day - turns out to be an illusion; and a very dangerous one. For if one really believes that such a solution is possible, then surely no cost would be too high to obtain it: to make mankind just and happy and creative and harmonious for ever - what could be too high a price to pay for that? (Berlin 1997a: 12-13).

In addition to Berlin, also J.L. Talmon, Karl Popper, and John Gray define utopia in perfectionist terms. For Talmon (1952: 252), utopia is defined as "complete harmony of interests, sustained without any resort to force, although brought about by force". For Karl Popper (1963: 358), utopianism is a view according to which "rational political action must be based upon a more or less clear and detailed description or blueprint of our ideal state, and also upon a plan or blueprint of the historical path that leads towards this goal". Utopia is a "distant ideal of society which is wholly good" (Popper 1963: 361). For Popper too, utopias are about absolute perfection. This kind of idea of utopia still lives on today for example in the work of John Gray who has described utopian thought as follows:

"The pursuit of a harmony defines utopian thought and discloses its basic unreality. Confict is a universal feature of human life. It seems to be natural for human beings to want incompatible things - excitement and a quiet life, freedom and security, truth and a picture of the world that flatters their sense of self-importance. A conflict-free existence is impossible for humans, and wherever it is attempted the result is intolerable to them. If human dreams were achieved, the result would be worse than any aborted Utopia. Luckily, visions of an ideal world are never realized. At the same time, the prospect of a life without conflict has a powerful appeal. In effect it is the idea of perfection attributed in some traditions to God. 
In religion the idea of perfection answers a need for individual salvation. In politics it expresses a similar yearning, but it soon runs up against other buman needs. Utopias are dreams of collective deliverance that in waking life are found to be nightmares." (Gray 2007: 17)

These conceptions of utopias can be described as "absolutist". They are absolutist in the sense that utopia is always a depiction of imagined perfection, absolute harmony, and closed totality. Utopia is a perfectly harmonious society from which (when it has been achieved) one cannot advance towards a better social totality.

This view on utopia is not, however, the only possible one. One can interpret utopias also in a relationalist manner. Relationalism refers to the fact that utopias cannot jump outside of history and claim to have found the best possible state of social being for humanity. And as such, relationalism refers to how utopias are always either explicitly or implicitly constructed in relation to the historical situation and in relation to the society they were created in. Relationalism interprets utopias as dynamic and non-perfectionist. In the relationalist interpretation, utopias are always criticisms, commentaries, and relativizations of the present in the form of an imaginary reconstitution of society (see Levitas 2013). Thus, utopias also change along with the changes to historical and social conditions.

The idea that utopias should not be understood as static blueprints but as somehow dynamic is not new. The relationalist view on utopia can already be seen in the work of science fiction writer H.G. Wells who in his A Modern Utopia (1905) writes about the kinetic qualities of utopia. According to Wells, the so-called modern utopia differs from the utopias that were written before Darwin in that the modern utopia is not static and perfect but kinetic and imperfect (but potentially perfectible). It is a part of long human evolution: after one utopia the next utopia will come. According to Wells (1905: 8), the modern utopia "must shape not as a permanent state but as a hopeful stage, leading to a long ascent of stages". Utopia was for Wells a process of ethical evolution that did not have an end state (see Partington 2000) and utopias that were imagined in the past are not the same that are imagined now.

Similarly to Wells, sociologist Karl Mannheim has also aimed to situate and ground utopias to the present. His ideas on utopia and ideology can be described as relationalist since he defines the concept of utopia in relation to the existing social order. One of Mannheim's key concepts is the concept of utopian mentality which is a state of mind that is incongruous "with the state of reality within it occurs" (Mannheim 1979: 173). A state of mind is utopian when it orients "towards objects which do not exist in the actual situation” (Mannheim 1979: 173). It transcends the immediate given situation and departs from reality. However, for this orientation to be truly utopian it has to have the tendency "to shatter, either partially or wholly, the order of things prevailing at the time", transcend the social reality and break "the bonds of the existing order" (Mannheim 1979: 173).

The utopian mentality can, however, sometimes be confused with ideological states of mind. For Mannheim, ideology is incongruent with reality as well, but it does not break the bonds of the existing order but rather ends up maintaining and reinforcing the existing order. Although this distinction sounds simple enough, in practice it is not easy to say which state of mind 
is ideological and which is utopian since the same ideas can take both forms depending on the historical situation. For example, liberalism can be seen as a utopian set of ideas during the rise of the bourgeoisie but later as the bourgeoisie consolidates its power it becomes an ideology which only maintains the existing order. Liberalism cannot offer revolutionary possibilities since it is now a set of ideas that has once transcended the existing order but can no longer provide utopian alternatives.

Every period in history has had ideologies which were harmoniously integrated into the dominant worldview. One example of this is Christian ideology of "the clerically and feudally organized medieval order" which "was able to locate its paradise outside of society, in some other-worldly sphere which transcended history and dulled its revolutionary edge, the idea of paradise was still an integral part of medieval society" (Mannheim 1979: 174). However, when certain social groups embodied this ideology and aimed to realize the idea of paradise it contained in the here and now, this ideology turned into utopia that oriented towards creating a new topos. Here Mannheim refers to Gustav Landauer's theory of revolution and calls "every actually existing and ongoing social order" a topia (Mannheim 1979: 174). As Landauer (2010: 112-113) writes in his essay:

"Revolution concerns communality in all its dimensions. This means not only the state, the estates of the realm, the religious institutions, economic life, intellectual life, schools, arts, or education, but the combination of all of those; a combination that, for a certain period of time, rests in a relative state of authoritative stability. We call this combination - the current state of communality - topia. Topia is responsible for affluence and satiation as well as for hunger, for shelter as well as for homelessness. Topia organizes all matters of communality, wages war, exports and imports, closes and opens borders. Topia implies intelligence and simplemindedness, virtue and vice, happiness and unhappiness, harmony and disharmony. Topia impacts on the sub-areas of communality (those that are not identical with topia itself): the private lives of individuals and families. The borders here are not clearly drawn."

In both Mannheim's theory of utopia and Landauer's theory of revolution, each topia is followed by utopia. Each historical situation creates utopias which in turn help to create a new topia, a new historical situation. There is no end to this process, there will always be new utopias to create new topias. Here too, utopias are understood in relation to the present and in relation to the topias they have grown out of.

In my own work (Lakkala 2020) I have also interpreted utopias in a relationalist manner. I have defined utopias as critical counter-images of the present motivated by a desire for a better being. This perspective emphasizes the so-called function of critique of utopias (Levitas 2010: 208). The construction of utopia is in itself a critical act. Utopia is always - implicitly or explicitly - critical towards the existing social order and it expresses the need and desire for social change. There is no need for the construction of utopias if the society itself is seen as perfect. Utopias would become obsolete if there was nothing to improve in the existing society.

Utopias force a comparison between the real, existing society and the imaginary and desired society, creating a contrasting effect that illuminates the injustices the existing 
society is facing. Just as Manuel and Manuel (1979: 446) write, building utopia as an antithesis and a counterpoint to reality is one of the oldest devices in the utopian writer's repertoire. This contrast is already visible in Thomas More's Utopia (1516) where the depiction of the Island of Utopia is compared side by side with the description of the poor conditions in which the people of England are forced to live. Utopias are counter-images that relativize the present (Bauman 1976: 13). This has two implications: (1) the present can always be imagined to be different as utopias communicate the idea that the present is socially and politically contingent; and (2) the present does not determine the future but can lead to a number of different futures depending on choices made in the present.

This dynamism and radical alternativity that utopian counter-images can offer should be specified. Two aspects of utopian counter-images should be distinguished: (1) the historically changing normative content of utopia and (2) the historically changing institutional form of the depicted utopian society. Both are ultimately historically variable, but these two aspects do not necessarily need to change together. There is no reason why we could not think of utopias where their institutional form has changed over time but the normative contents of utopias have stayed more or less the same.

We can use the communist utopia as an example to illuminate this distinction. Friedrich Engels (1969: 81) writes in his The Principles of Communism that communism "is the doctrine of the conditions of the liberation of the proletariat". This definition expresses the view that instead of a fixed and static finality, communism is an emancipatory horizon that changes according to the historical circumstances and the political agency of the proletariat. One can argue that although the institutional form of communism needs to take into consideration the changing historical circumstances, the normative content or the deeper intention of communism does not have to. The utopia of communism the utopia of a world where all relations "in which man is a debased, enslaved, abandoned and despicable essence" (Marx 1970) are overthrown - can be seen as an invariant normative content in all the different institutional forms this utopia can take. The normative content of an utopia and the institutional form it takes ought to be distinguished. We can commit to the moral vision of communism and still be open to the variation it takes on an institutional level.

Utopian counter-images can be seen as visions of alternative social reality where the problems that are seen as most pressing in the present are solved and the core contradictions have been overcome. For example, one can see the vision of communist society as a utopian counter-image proposing a solution to the core contradictions of capitalism (the contradictions between labor, capital and nature). Utopianism as a form of critical philosophy crystallizes the core problems of the present and forces us to question the collective goals of the existing society. The purpose of utopianism is not to create static and absolutist blueprints for a new society but to create critical counter-images of a society in which radically new principles and practices are created. The role of utopias as counter-images of the current society makes them relational and historically conditioned. Utopias are critical reflections of the existing social institutions, social relations, and the social totality as a whole. 
However, it would be naive to think that utopias can reflect the present without any mediations. It would be a symptom of an uncritical epistemology to claim that utopias reflect the problems of the existing society as such. A utopian counter-image that aims to solve the core problems of the present cannot be constructed without any theoretical vision and analysis of the present itself. Without any theoretically articulated vision of the present and its central tendencies and latent potentialities, utopia cannot be useful as a tool of social criticism. Utopian counter-images are not unproblematic reflections of the current historical situation but always conceptually mediated: the nature of the utopian counter-image depends on how we understand and conceptualize the present. This brings us to 'the Anthropocene' and its way of conceptualizing the "epoch of man".

\section{Anthropocene and Utopia}

Although the Anthropocene is sometimes referred to as an event of social realization after which we are forced to change our worldview on geopolitical, economic, and even rhetorical levels (Bonneuil \& Fressoz 2016), it is a concept that has been mainly used to describe the current epoch of humanity. The Anthropocene emerges as a geological epoch when significant human impact on the Earth, its geology, and its ecosystems can be detected. It has been established as an epoch during which humans have started to transform the Earth and its ecosystems on a planetary scale. Anthropocene means a transition from the Holocene to the "epoch of Man" on a geological scale.

The starting points suggested for this epoch can be distinguished into three main levels: (1) early Anthropocene starting from some thousands of years ago, (2) the beginning of the Industrial Revolution in the 19th century, and (3) the "Great Acceleration" of the mid-twentieth century (Zalasiewicz et al. 2015). Although Paul Crutzen (2002) has in his seminal article located the beginning of the Anthropocene at the end of the $18^{\text {th }}$ century and the beginning of the Industrial Revolution, it was not until the $20^{\text {th }}$ century when the changes made by humans to the Earth's stratum became stratigraphically identifiable (Zalasiewicz et al. 2015).

Although the word 'Anthropocene' has its origins in natural sciences, it has also become a descriptor of the current social epoch. The Anthropocene can be observed through natural sciences but its origins are cultural and social. Thus, it is fertile ground for political debates. There is no single concept of the Anthropocene but rather an Anthroposcene in which different social and historical discourses about the 'epoch of Man' are circulated (Alhojärvi 2017).

In addition to these specific forms of the concept, the Anthropocene can also be seen as a historical narrative that not only answers the question "When did the Anthropocene begin?" but also the question "How (or why) did we end up in the Anthropocene?". According to Toivanen and Pelttari (2017), to answer these questions one needs to construct a narrative that frames and gives meaning to the geological footprints' humans have caused. The mainstream version of this narrative has been a story about the evolution of humans and their societies from hunter-gatherers into a global geological force. Anthropocene has become a progressive metanarrative about the general evolution of mankind (Toivanen 
\& Pelttari 2017). An abstract "Man in General", Anthropos, is at the heart of this narrative. The abstract human is the subject of this world-historical process.

The Anthropocene has two lives: one as an academic discourse and one "as a broader conversation that transcends the university" (Moore 2016b: 80). The geological concept of the Anthropocene has expanded into an Anthroposcene - an epistemic community which produces knowledge about the natural and political planetary scale changes (see Alhojärvi 2017; Castree 2015; Lorimer 2017). In natural sciences the concept of the Anthropocene might be useful but as the notion transforms into a historical narrative or a form of general discourse, it becomes more problematic (Crist 2016: 15). Not only is the idea of 'Man in General' problematic when we talk about humans in different positions in the social hierarchy but also the narrative of Anthropocene tends to reproduce the problematic dualism between Nature and Society influential in modern thought. As Jason W. Moore (2016a: 3) writes: "The Anthropocene argument shows Nature/ Society dualism at its highest stage of development".

This problem of the Anthropocene has been acknowledged relatively widely and some alternatives has been suggested. As examples of these alternatives one can mention Technoscene (see for example Cera 2017), Naphtocene (the epoch of oil) (Vadén 2017), Growthocene (Chertkovskaya \& Paulsson 2016), Capitalocene, Necrocene (McBrien 2016), and Chthulucene (Haraway 2016).

In addition to the dualism and the abstract notion of humanity, I argue that the Anthropocene has the potential to negatively affect our capability to think of concrete alternatives for our current situation. It obstructs our socio-political imagination and prevents us from creating utopian counter-images to the present. What kind of utopias (relationalist counter-images) can we develop from the image of the present that the Anthropocene offers? Because of its conception of the abstract human and the undialectical opposition between Nature and Society, the utopian counter-images of the Anthropocene are concerned with humanity in general.

As a political discourse and a narrative of the evolution of humanity, the Anthropocene can contain either positive or negative images of mankind. On the one hand, the Anthropocene narrative depicts an image of man who has almost God-like powers to change the very geology of the Earth. The Anthropocene discourse "delivers a Promethean self-portrait" of mankind (Crist 2016: 16) that relies on the Foucauldian idea of "Geopower" through which the Earth becomes scientifically managed (see for example Blühdorn 2007; Bonneuil \& Fressoz 2016: 88; Luisetti 2019: 351).

The so-called "Good Anthropocene" thesis (see Dalby 2015) can be defined as a faith in the ability of humanity to collectively assert control over socio-ecological systems to good effect (Dryzek \& Pickering 2019). This thesis can also be described as utopian since it expresses a desire for a significantly better world. Examples of this thesis can be found for example from the Breakthrough Institute's The Ecomodernist Manifesto (Asafu-Adjaye et al. 2015), Leigh Phillips“ Austerity Ecology \& the Collapse Porn Addicts: A Defence Of Growth, Progress, Industry and Stuff (2015), and Aaron Bastani's Fully Automated Luxury Communism (2018). All of these texts code the Anthropocene with utopian anticipation. 
In the Good Anthropocene, humanity has not gone too far in transforming the Earth and its ecosystems. Rather, the task is to go even further in transforming the Earth according to human needs and desires.

On the other hand, the Anthropocene discourse can also depict humanity as a parasite on Earth that continues destroying the natural environments of other life forms. The Bad Anthropocene narrative includes misanthropic dimensions that encode the epoch with dystopian meaning. This misanthropic dimension has been articulated for example by Mark Whitehead (2014: 163):

"D]iscussion of the Anthropocene can be a fertile breeding ground for misanthropy (the hatred of humans). Those of a deep green perspective, for example, argue that the response to the current imbalances in the global ecosystem should involve a return to a natural balance, in and through which the needs of the environment prioritized over those of humans."

These misanthropic ideas can offer utopian counter-images that envision a world without humans. For example, Alan Weisman has envisioned a utopia without humanity in his book The World Without Us (2007). Jendrysik (2011: 35-36) has described this kind of utopianism as follows:

"These works combine utopian dreaming, science and science fiction prediction, and a sort of religious vision. They demonstrate our need for utopia. But they modify that need and in doing so perhaps become a new form of critical utopia. Traditionally, utopian thought demonstrates the human desire for a better life in the present or in some near term. But these works suggest that our society is so hopeless that the best result we can expect is not to destroy the world as we destroy ourselves. They might be an ironic form of critical utopia, suggesting that humans recognize that we are the greatest obstacle to utopia. These works take a position of estrangement not just from existing society but from Homo sapiens and call for a radical revaluation of human and natural things. They ask us to consider if utopia is now possible only in the absence of humanity."

The more positive versions of the Anthropocene discourse seem to rely heavily on the humanist Enlightenment tradition of thought that offers a counter-image to the imperfect and ignorant humanity in the form of fully enlightened humanity. For this tradition, humanity is perfectible through progressive processes guided by reason, science, and technology. An example of this kind of thinking can be found from transhumanist thought where the utopian goal can be expressed through the idea of enhanced humanity whose bodily and cognitive limitations have been overcome and humanity has been perfected (Bostrom 2008). Usually this perfection will, in the transhumanist narrative, become a reality after an eschatological event called the Singularity, "when the machines will surpass human intelligence" (Paura 2016: 25; see also Kurzweil 2005; Vinge 2013).

Transhumanist thought has its roots in the old technological utopias of early modernity (see for example, Bacon 1890). What is new, however, is that with today's technology, radical alteration and "perfection" of the human body and mind seems a real possibility (Hauskeller 2012: 44). Transhumanism still clings on to the notion of abstract man when it creates a counter-image to humanity-as-it-exists-today. It does not abandon the notion of man as such but aims to go beyond it: 


\begin{abstract}
“Trans-human' emphasizes the way transhumanism goes well beyond humanism in both means and ends. Humanism tends to rely exclusively on educational and cultural refinement to improve human nature whereas transhumanists want to apply technology to overcome limits imposed by our biological and genetic heritage. Transhumanists regard buman nature not as an end in itself, not as perfect, and not as having any claim on our allegiance. Rather, it is just one point along an evolutionary pathway and we can learn to reshape our own nature in ways we deem desirable and valuable. By thoughtfully, carefully, and yet boldly applying technology to ourselves, we can become something no longer accurately described as human - we can become posthuman. " (More 2013: 3)
\end{abstract}

The image of man in transhumanist thought can be seen both as a radical alteration of man and overcoming the category of man altogether. It is a radical alteration of humanity to the point where humanity as we know it ceases to exist. In this sense, it is a natural part of larger posthumanist thought that also wants to overcome the category of man. There are certainly differences between transhumanism and, for example, the kind of posthumanism represented by Donna Haraway (2004) but they are negatively connected in their aspiration to overcome the traditional humanist notions of man.

For posthumanism the category of man is purely an ideological construction. Posthumanist thought denies the essential distinction and hierarchy between the human and the non-human and it examines the ways this distinction and hierarchy can be dissolved. In posthumanist thought the dichotomies between mind and body, animal and human, organism and machine, public and private, nature and culture, men and women, primitive and civilized are questioned. In Haraway's (2004: 9) posthumanism, the utopian counter-image to the image of Man is the image of "the Cyborg":

"The cyborg is resolutely committed to partiality, irony, intimacy, and perversity. It is oppositional, utopian, and completely without innocence. No longer structured by the polarity of public and private, the cyborg defines a technological polis based partly on a revolution of social relations in the oikos, the household. Nature and culture are reworked; the one can no longer be the resource for appropriation or incorporation by the other. The relationships for forming wholes from parts, including those of polarity and hierarchical domination are at issue in the cyborg world. "

Unlike in the Enlightenment and transhumanist thought where the point is the perfectibility of man, in posthumanist thought the point is to overcome the category of Man and give room for the multiple forms of being that have been suppressed and left outside of this rigid category. Kortekallio (2020: 22) has argued that posthuman philosophy aims to change the way humans perceive themselves as humans in order to develop a sustainable way of living. In posthumanism, it is not so much that we aim to change humanity itself but our understanding of what it means to be human. Posthuman thought looks for an alternative, nonessentialist and non-hierarchical ways for understanding the qualities and relations between different kinds of beings (Lummaa \& Rojola 2014: 14). For example, the idea of the Human is not defined in opposition to the non-Human but these categories are in constant fluctuation. 
The critical posthumanist examinations of the category of human can be interesting, useful, and important but if we want to look for societal alternatives for the present, we need to conceptualize the present in a different manner. The concept of Human should not be used as a starting point - as it is used in both the (Good and Bad) Anthropocene discourse and posthuman thought. The focus on humanity as such can sideline the socially differentiated conditions of humanity and the multitude of historical human societies (Durkheim 1982: 109). This is also why the utopias derived from the Anthropocene can easily dismiss some important social formations (e.g., the formation of nation-states, the interrelations of the economy and ecology, and class divisions) (Toivanen \& Pelttari 2017). This leads the search for societal alternatives astray and negatively affects our socio-political imagination. After all, it is not in vain that the utopian theory emphasizes utopias as being part of the tradition of social dreaming (Sargent 1994: 3-7). The social character of utopianism is in danger of disappearing in the utopian counter-images derived from the Anthropocene discourse.

It is, of course, clear that the concept (and even the discourse) of Anthropocene reflects the very real transformation of the planet Earth. The changes that have been identified stratigraphically on Earth are real and their effects can be devastating. A transition from Holocene to a new epoch is real. However, the abstract man as the subject of these changes leads to a utopian cul-de-sac. A concept is needed that both acknowledges this transition to a new epoch but at the same time allows us to think of concrete utopian (see Bloch 1986) social alternatives. I argue that the concept of the Capitalocene can offer a way out.

\section{Naming the System}

Mass extinctions, climate change, and ocean acidification are real environmentally destructive processes. But they are not consequences of the actions of abstract Man, humanity in general, industrial civilization, or of the West. They are consequences of the Capitalocene and capitalist world-ecology. Jason W. Moore's world-ecology approach argues for the dissolution of both abstract notions of Nature and Society and replacing them with a more dialectical conception of nature-in-humanity and humanity-in-nature (Moore 2015: 1-32). Here the term world-ecology does not refer to the ecology of abstract Nature separated from mankind but to the "creative, generative, and multilayered relation of life-making, of species and environments" (Moore 2016b: 79).

According to the world-ecology approach, species make environments and environments make species. And in the case of humans, the human activity itself is environment-making. To be more precise, human (social) organizations are environment-making processes and projects which shape the web of life which in turn shapes the way humans are organized. Historical change is tied to the dialectics of (diverse and differentiated) humanity and nature in internal and concrete (and not in external and abstract) relations with each other. According to Moore (2016b: 79), there is a double internality between humans (and the way they are organized) and nature: "humanity inside nature, nature inside humanity". Human social organizations, human societies are part of nature and nature is part of human societies.

From this perspective, one can study how a specific form of human organization, 
capitalism, both produces the environment and the web of life and is produced by the web of life itself (Moore 2016b: 79). Thus, the alternative social organizations that can be developed as counterimages to the present capitalist social organization become more visible. What kind of counter-world-ecologies can and should be created against the image of the capitalist world-ecology?

One of the fundamental processes of the capitalist world-ecology has to do with the new ways of knowing developed in early modernity. These new ways of knowing were symbolic but their consequences were concretely material: they caused both the commodification of human labor and turning land into property. In other words, it was one of the conditions which Karl Marx (1976: 873) called "primitive accumulation". By primitive accumulation, Marx refers to the processes that made workers dependent on selling their labor in order to survive and, as David Harvey (2003: 148) points out, to the processes of the commodification of nature in all its forms. Like the separation of the worker from the means of production and the peasants from the land, these new ways of knowing were premised on separation and on the alienation of Humanity and $\mathrm{Na}$ ture from each other. This separation was, of course, illusory and mostly conceptual. Humanity did not really escape Nature. Only the relation between the two changed in a complex and protracted process in which the symbolic and material became bundled. This process took the form of world-praxis that aimed to remake the world in the image of capital. Structures of thought prioritized dualism and the separation of Humans from Nature (Moore 2016b: 86).

In this dualism, Humanity represented Civilization or Society and those who were not seen as "civilized" became part of Nature: "From the beginning of capitalism [...] most humans were either excluded from Humanity - indigenous Americans for example - or were designated as only partly Human, as were virtually all European women. [...] [T] he symbolic boundaries between who was - and who was not - part of Nature (or Society) tended to shift and vary" (Moore 2016b: 87). Despite being purely symbolic, these dualistic boundaries had real material effects. Not only did they justify atrocities from slavery to genocide, they also ignited long historical struggles in gaining full Humanity to those excluded from it. It is not an exaggeration to say that this struggle is still going on.

The Humanity/Nature dualism that can also be recognized in the Anthropocene discourse was fundamental to the rise of capitalism. The dualistic ontology of the natural world meant that Nature could be reduced to external objects that could be mapped, explored, and calculated. Nature would become a series of external objects that could be appropriated into the circuit of capital and, thus, a seemingly endless resource for the accumulation of capital (Moore 2016b: 87). Nature became "cheap" (Moore 2016b: 99). Today capitalism still relies on the unpaid work of Cheap Nature. Capitalism has mobilized the work of nature by capturing the work/energies of the biosphere (Moore 2016b: 111) and capitalism cannot exist without the appropriation of these resources provided by nature. As Mies, Bennholdt-Thomsen \& von Werlhof (1988: 6) write, along with different types of non-wage labor (e.g. housework done by women) and colonial labor of the periphery, nature is one of the main targets of the process of ongoing primitive accumulation. Along with women and colonies, nature 
forms an inner colony of capitalism (Fuchs 2018: 462).

We can now present the system of Cheap Nature and capitalism as our image of the present. Capitalism is not a closed system separated from nature that interacts with it externally, but a world-ecology and a world-praxis. It is an open system and an environment creating praxis within nature that is based on the strategy of Cheap Nature (Moore 2016b: 113). The consequences recognized in the Earth's ecosystems and its geology are not the result of humanity in general but because a specific form of human social organization (capitalism) has come to dominate humanity's world-praxis. Understanding this will allow us to look for alternative ways of arranging our environment creating praxis' and to look for alternative world-ecologies that are more sustainable and more in balance with the ecosystems of the Earth.

The Capitalocene helps in developing utopian counter-images that are not grounded on the abstract human, or humanity in general but on the specific systems of organizing the web of life. The notion of Capitalocene names a system and that way opens up the possibility to imagine alternatives. As Tanner Mirrlees (2015: 8) has written, naming the system "remains the precondition for all attempts to understand and change it". The Anthropocene does not have this social openness. In fact, the Anthropocene discourse naturalizes historical and social processes and this way also depoliticizes them (see Swyngedouw 2011). As Andreas Malm and Alf Hornborg (2014: 67) have outlined, the Anthropocene might function as an ideological discourse that can "block off any prospect of change". It might fatally weaken the social and political imagination needed for radical social transformation.
From the point of view of utopian theory, it can be argued that the concepts of Anthropocene and Capitalocene have different functions within the social imaginary. Since the Anthropocene enables utopian alternatives only for abstract Man and dismisses the societal dimension of utopianism, it can only leave the current social order untouched. This way the notion of Anthropocene seems to provide mainly unintended support for the existing social relations, processes, and structures. Although the notion of Anthropocene (both the "Good" and the "Bad" versions of it) might not be intended as ideological support for the existing social order, it might very well function as such. The concept of the Capitalocene on the other can possibly enable more radical and therefore more utopian thinking by offering a clear social starting point for the creation of utopian counter-images. And by interpreting Capitalocene mainly as a historically developed (and therefore contingent and not essential) world-ecological world-praxis, alternative world-praxis' can become more visible.

\section{Epilogue}

What are the critical counter-images to the present that we can derive after the recognition of the Capitalocene? These alternatives can take multiple forms and some of them are more realistic than others.

One possible example of a utopian counter-image to Capitalocene and its strategy of Cheap Nature can be found from the degrowth theory and movement. Serge Latouche has in his Limits to Growth (2009: 32) presented a concrete utopia of a nongrowth society. This utopia is a political project of "building convivial societies that 
are autonomous and economical in both the North and the South" (Latouche 2009: 32). In this form of utopianism, ecological crisis is aimed to be solved through limiting consumption. Degrowth means "reducing the impact of our ways of consuming and producing on the biosphere" (Latouche 2009: 38). Degrowth means an anti-productivist, anti-capitalist, and anti-utilitarian form of utopianism that does not rely on the strategy of Cheap Nature. Degrowth has also been described as utopia that "imagines a future of process and conflict, not a blissful end state" and it "subverts the hegemonic desires on which capitalism rests" (Kallis \& March 2015: 368). It is not a static, absolutist form of utopia, but a radical, relational, and concrete alternative to both capitalism and modernity at large. However, it is not necessarily a fully anti-modernist or anti-Enlightenment form of utopianism:

"The critique of modernity does not imply that we must simply reject it; it means, rather, that we have to transcend it. We have to denounce its bankruptcy and the triumphant beteronomy of the dictatorship of financial markets in the name of the emancipatory project of the Enlightenment and the construction of an autonomous society." (Latouche 2009: 103).

Another example of a utopian counter-image to Capitalocene is ecosocialism. There are many different forms of ecosocialism (see for example Pepper 1993; Borgnäs et al. 2015; White et al. 2017; Saito 2017) but in general they can be described as utopias aiming to combine the demands of social justice and environmental sustainability. Ecosocialism wants to hold on to the radical democratic spirit of socialist tradition but at the same time abandon the more harmfully productivist ideas of that same tradition. For the ecosocialist, neither the criticism of consumerism, the social-liberal programs of capitalist management nor the red-green governmental coalitions between the social democrats and the greens are enough. Ecosocialism aims for another kind of world-praxis altogether. As Michael Löwy (2015: x) has written:

"The cultural criticism of consumerism is
necessary but insufficient: one has to challenge
the mode of production itself. Only a collective
and democratic reorganization of the produc-
tive system could, at the same time, satisfy real
social needs, reduce labor time, suppress useless
and/ or dangerous production, and replace fuels
with renewable energy sources. All this re-
quires deep incursions into capitalist propriety,
a radical extension of the public sector, and,
in a word, a democratic, ecosocialist plan."

The utopian eco-socialist counter-images should merit further examination. The important aspect is that the utopian visions of ecosocialisms can be seen as counter-images to capitalism and the Capitalocene. All the examples of possible counter-images presented here name the system and start the development of their utopian visions from the analysis of capitalism and not from the ideological delirium of the Anthropocene discourse. The utopian counter-images should not be derived from the abstract Man but from historical human beings in different social, economic, and political relations with each other. Only by focusing our critical capabilities on the social relations that condition human life, can we start developing utopian counter-images to the present. 


\section{Acknowledgements}

I want to especially thank the anonymous reviewers for their valuable comments and the editors of this Yearbook. I also want to thank the Department of Social Sciences and Philosophy of University of Jyväskylä for funding of my research during the time this article was finished.

\section{References}

Alhojärvi, T. (2017). Yllättymisiä: antroposkenen paranoia ja tiedon tilanteinen ongelma. Tiede \& Edistys 42: 1, 36-56.

Asafu-Adjaye, J., F. Christopher, P. Rachel, B. Linus, K. David, R. Jayashree, L. Martin, B. Stewart, M. Sagoff, B. Brook, M. Lynas, M. Shellenberger, R. Defries, T. Nordhaus, R. Stone, E. Ellis, R. Pielke \& P. Teague (2015). An Ecomodernist Manifesto. <http://www.ecomodernism.org/manifesto-english> (accessed 8 Dec 2020).

Bacon, F. (1890). New Atlantis. In Morley, H. (eds.): Ideal Commonwealths, 171-213. George Routledge and Sons, London.

Bastani, A. (2018). Fully Automated Luxury Communism. 278 p. Verso Books, London.

Bauman, Z. (1976). Socialism. The Active Utopia. 150 p. George Allen \& Unwin Ltd, London.

Berlin, I. (1997a). The Pursuit of the Ideal. In Hardy, H. \& R. Hausheer (eds.): The Proper Study of Mankind. An Anthology of Essays, 1-16. Chatto \& Windus, London.

Berlin, I. (1997b). Two Concepts of Liberty. In Hardy, H. \& R. Hausheer (eds.): The Proper Study of Mankind. An Anthology of Essays, 191-242. Chatto \& Windus, London.

Bloch, E. (1986). The Principle of Hope. Volume One. 448 p. The MIT Press, Cambridge.

Blühdorn, I. (2013). The governance of unsustainability: ecology and democracy after the post-democratic turn. Environmental Politics 22: 1, 16-36.

Bonneuil, C. \& J. Fressoz (2016). The Shock of the Anthropocene: The Earth, History and Us. 306 p. Verso Books, London.

Bostrom, N. (2008). Why I Want to be a Posthuman when I Grow Up. In Gordijn B., R. Chadwick (eds.): Medical Enhancement and Posthumanity, 107-137. Springer, Dordrecht.

Borgnäs, K., Eskelinen, T., Perkiö, J., \& Warlenius, R. (Eds.). (2015). The Politics of Ecosocialism: Transforming Welfare. Routledge.
Castree, N. (2015). Changing the Anthropocene(s): Geographers, global environmental change and the politics of knowledge. Dialogues in Human Geography 5: 3, 301-316.

Cera, A. (2017). The Technocene or Technology as (Neo)Environment. Tecnhé: Research in Philosophy and Technology 21: 2, 243-281.

Chertkovskaya, E. \& A. Paulsson (2016). The growthocene: Thinking through what degrowth is criticising. ENTITLE blog. <https://entitleblogdotorg3.wordpress.com/2016/02/19/the-growthocene-thinking-through-what-degrowth-is-criticising/amp/> (accessed 8 Dec 2020)

Claeys, G. (2017). When Does Utopianism Produce Dystopia? In Czigányik, Z. (eds.): Utopian Horizons. Ideology, Politics, Literature, 41-62. Central European University Press, Budapest.

Crist, E. (2016) On the Poverty of Our Nomenclatura. In Moore, J. W. (eds.): Anthropocene or Capitalocene? Nature, History, and the Crisis of Capitalism, 14-33. PM Press, Oakland.

Crutzen, P. J. (2002). Geology of Mankind. Nature 415: 23, 2002.

Dahrendorf, R. (1958). Out of Utopia: Toward a Reorientation of Sociological Analysis. American Journal of Sociology 64: 2, 115-127.

Dalby, S. (2015). Framing the Anthropocene: The good, the bad and the ugly. The Anthropocene Review 3: 1, 33-51.

Dryzek, J. S. \& J. Pickering (2019). The Politics of the Anthropocene. 196 p. Oxford University Press, Oxford.

Durkheim, E. (1982). The Rules of Sociological Method and Selected Texts on Sociology and its Method. 269 p. The Free Press, New York.

Engels, F. (1969). The Principles of Communism. In Marx, K. \& F. Engels: Selected Works, Vol. 1., 81-97. Progress Publishers, Moscow.

Fuchs, C. (2018). Universal Alienation, Formal and Real Subsumption of Society under Capital, Ongoing Primitive Accumulation by Dis-possession: Reflections on the Marx@200-Contributions by David Harvey and Michael Hardt/Toni Negri. tripleC 16: 2, 454-467.

Gray, J. (2007). Black Mass: Apocalyptic Religion and the Death of Utopia. 256 p. Allen Lane, London.

Haraway, D. (2004). Manifesto for Cyborgs: Science, Technology, and Socialist Feminism in the 1980s. In Haraway D. (eds.): The Haraway Reader, 7-45. Routledge, London.

Harvey, D. (2000). Spaces of Hope. 293 p. University of California Press, Berkeley.

Harvey, D. (2003). The New Imperialism. 275 p. Oxford University Press, Oxford. 
Haraway, D. (2016). Staying with the Trouble: Anthropocene, Capitalocene, Chthulucene. In Moore, J. W. (eds.): Anthropocene or Capitalocene? Nature, History, and the Crisis of Capitalism, 34-76. PM Press, Oakland.

Hauskeller, M. (2012). Reinventing Cockaigne: Utopian Themes in Transhumanist Thought. Hastings Center Report 42: 2, 39-47.

Jendrysik, M. S. (2011). Back to the Garden: New Visions of Posthuman Futures. Utopian Studies, 22: 1, 34-51.

Kallis, G. \& H. March (2015). Imaginaries of Hope: The Utopianism of Degrowth. Annals of the Association of American Geographers 105: 2, 360-368.

Kortekallio, K. (2020). Reading Mutant Narratives: The Bodily Experientality of Contemporary Ecological Science Fiction. 283 p. University of Helsinki, Helsinki.

Kurzweil, R. (2005). The Singularity Is Near. When Humans Transcend Biology. 652 p. Viking Press, New York.

Lakkala, K. (2020). Disruptive Utopianism: Opening the Present. In Eskelinen, T. (eds.): The Revival of Political Imagination. Utopias as Methodology, 20-36. Zed Books, London.

Landauer, G. (2010). Revolution. In Kuhn, G. (eds.): Revolution and other writings. A Political Reader, 110-187. PM Press, Oakland.

Latouche, S. (2009). Farewell to Growth. 180 p. Polity Press, Cambridge.

Levitas, R. (2010). The Concept of Utopia. 264 p. Peter Lang, Bern.

Levitas, R. (2013). Utopia as Method: The Imaginary Reconstitution of Society. 288 p. Palgrave Macmillan, New York.

Lorimer, J. (2017). The Anthropo-scene: A guide for the perplexed. Social Studies of Science 47: 1, 117-142.

Luisetti, F. (2019). Geopower: On the states of nature of late capitalism. European Journal of Social Theory 22: 3, 342-363.

Lummaa, K. \& L. Rojola (2014). Johdanto: Mitä posthumanismi on? In Lummaa, K. \& L. Rojola (eds.): Posthumanismi, 13-32. Eetos, Turku.

Löwy, M. (2015). Ecosocialism. A Radical Alternative to Capitalist Catastrophe. 144 p. Haymarket Books, Chicago.

Malm, A. \& A. Hornborg (2014). The geology of mankind? A critique of the Anthropocene narrative. The Anthropocene Review 1: 1, 62-69.

Mannheim, K. (1979). Ideology and Utopia. An Introduction to the Sociology of Knowledge. 318 p. Routledge \& Kegan Paul, London/Henley.

Manuel, F. E. \& F. P. Manuel (1979). Utopian Thought in the Western World. 912 p. Basil Blackwell,
Oxford

Marx, K. (1976). Capital. A Critique of Political Economy. Volume One. 1141 p. Penguin Books, New York.

Marx, K. (1970). Critique of Hegel's Philosophy of Right. pp. 143. Cambridge University Press, Cambridge.

Marx, K. \& F. Engels (1976). The German Ideology. Critique of Modern German Philosophy According to Its Representatives Feuerbach, B. Bauer and Stirner, and German Socialism According to Its Various Prophets. pp. 661. Lawrence \& Wishart, London.

McBrien, J. (2016). Accumulating Extinction: Planetary Catastrophism in the Necrocene. In Moore, J. W. (eds.): Anthropocene or Capitalocene? Nature, History, and the Crisis of Capitalism, 116-137. PM Press, Oakland.

McKinna, E. (2001). The Task of Utopia: A Pragmatist and Feminist Perspective. 179 p. Rowman \& Littlefield Publishers, Oxford.

Mies, M., V. Bennholdt-Thomsen \& C. von Werlhof (1988). Women: The Last Colony. 185 p. Zed Books, London.

Mirrlees, T. (2015). Hollywood's uncritical dystopias. CineACTION 95, 4-15.

More, M. (2013). The Philosophy of Transhumanism. In More, M. \& N. Vita-More (eds.): The Transhumanist Reader, 3-17. Wiley-Blackwell, Sussex.

Moore, J. W. (2015). Capitalism in the Web of Life: Ecology and the Accumulation of Capital. 320 pp. Verso Books, London.

Moore, J.W. (2016a). Introduction: Anthropocene or Capitalocene? Nature, History, and the Crisis of Capitalism. In Moore, J. W. (eds.): Anthropocene or Capitalocene? Nature, History, and the Crisis of Capitalism, 1-11. PM Press, Oakland.

Moore, J. W. (2016b) The Rise of Cheap Nature. In Moore, J. W. (eds.): Anthropocene or Capitalocene? Nature, History, and the Crisis of Capitalism, 78-115. PM Press, Oakland.

Partington, J. (2000). The Death of the Static: H.G. Wells and the Kinetic Utopia. Utopian Studies 11: 2, 96-111.

Paura, R. (2016). Singularity Believers and the new utopia of Transhumanism. Im@go. A Journal of Social Imaginary 7, 23-55.

Pepper, D. (1993). Ecosocialism. From Deep Ecology to Social Justice. 288 pp. Routledge, London.

Phillips, L. (2015). Austerity Ecology \& The Collapse-Porn Addicts. A Defence of Growth, Progress, Industry and Stuff. 304 pp. Zero Books, Winchester.

Popper, K. R. (1963). Conjectures and Refutations. The Growth of Scientific Knowledge. 431 pp. Routledge \& Kegan Paul, London. 
Jacoby, R. (2005). Picture Imperfect. Utopian Thought for an Anti-Utopian Age. 241 pp. Columbia University Press, New York.

Saito, K. (2017). Karl Marx's Ecosocialism. Capitalism, Nature, and the Unfinished Critique of Political Economy. 386 pp. Monthly Review Press, New York.

Sargent, L. T. (1994). Three faces of utopianism revisited. Utopian Studies 5:1, 1-37.

Sargent, L. T. (2010). Utopianism. A Very Short Introduction. 145 pp. Oxford University Press, New York.

Stirner, M. (1995). The Ego and Its Own. 428 pp. Cambridge University Press, Cambridge.

Swyngedouw, E. (2011). Depoliticized Environments: The End of Nature, Climate Change and the Post-Political Condition. Royal Institute of Philosophy Supplement 69, 253-274.

Talmon, J. L. (1952). The Origins of Totalitarian Democracy. 366 pp. Mercury Books, London.

Toivanen, T. \& M. Pelttari. (2017). Tämä ihmisen maailma? - Planeetan hätätila, antroposeenikertomuksen kritiikki ja antroposeenin vaihtoehtoinen historia. Tiede \& Edistys 42: 1, 6-35.

Vadén, T. (2017). Antroposeenin ihminen kulkee unessa. Peruste. 31.5.2017. <https://perustelehti.fi/antroposeenin-ihminen-kulkee-unessa/> (accessed 8 Dec 2020).

Vinge, V. (2013). Technological Singularity. In More, M. \& N. Vita-More (eds.): The Transhumanist Reader, 365-375. Wiley-Blackwell, Sussex.

Weisman, A. (2007). The World Without Us. 324 pp. St. Martin's Press, New York.

Wells, H. G. (1905). A Modern Utopia. 285 pp. Feedbooks, Paris.

White, D. F., B. J. Gareau \& A. P. Rudy (2017). Ecosocialisms, Past, Present and Future: From Metabolic Rift to a Reconstructive, Dynamic and Hybrid Ecosocialism. Capitalism, Nature, Socialism 28: 2, 22-40.

Whitehead, M. (2014). Environmental Transformations. A geography of the Anthropocene. 190 p. Routledge, London.

Zalasiewicz, J., C. N. Waters, M. Williams, A. D. Barnosky, A. Cearreta, P. Crutzen, E. Ellis, M. A. Ellis, I. J. Fairchild, J. Grinevald, P. K. Haff, I. Hajdas, R. Leinfelder, J. McNeill, E. O. Odada, C. Poirier, D. Richter, W. Steffen \& C. Summerhayes. (2015). When did the Anthropocene begin? A Mid-twentieth Century Boundary Level is Stratigraphically Optimal. Quaternary International 383, 196-203. 